\title{
Chapter 12 Appendix: All About Working with the Data
}

\begin{abstract}
The appendix provides the reader with detailed information about the sample, on how data have been collected and which challenges could be identified. The sample is described in terms of selection of the sample, selection of the research sites, the participants and their socio-economic backgrounds.
\end{abstract}

\section{Methods Used in the Research Process}

The situations of the children participating in the research were looked at from different perspectives by using interviews, observations and other methods. Hence, the following participants were addressed:

- Children with disabilities as subjects who speak about their own experiences

- Parents, legal guardians or other educators (professional as well as non-professional)

- Experts of the education system and disability in general (government, NGOs, colleges, university, etc.)

The empirical design of the study included:

- Guided interviews (with parents, children (using cue cards/pictures and other supportive material), teachers and further ${ }^{1}$ experts)

- Narrative interviews (with parents and teachers)

- Focus group discussions (with parents and children)

- Observations of classrooms during class and schoolyards in the breaktime

- Appraisals of the environment of the school

- Writing a research diary

Narrative and guided interviews were analysed in depth in the literature. Their potentials as well as the problems that arise while applying these methods have been pointed out by several authors (Clandinin 2007; Denzin and Lincoln 2005; Friebertshäuser and Prengel 1997; Glinka 2009). Guided interviews are especially useful for those phases of research where content fields have already been

${ }^{1}$ The "further" in "further experts" indicates that children and parents are also perceived as experts. 
prestructured. Narrative interviews on the other hand enable the researcher to make use of the biographical perspective. Therefore, it makes sense to use this method at the beginning of the empirical research as it can help to capture unexpected features. The observations and appraisals as well as the research diary influenced the research process, as they were incorporated in the researcher's reflections on the ongoing research process as well as in the analysis.

\section{Collection of Data}

I had the possibility to visit the field of the investigation four times. The first visit served for preparatory purposes, during the second visit (first phase of field research) I started interviews and observations in the field, and the third and fourth visit (second and third phase of field research) served for more intense consultation of the same and additional sources and participants, after having identified topics that emerged through interview analyses from the first phase of the field research.

In preparation for the first phase of field research (first guided interviews), questions had been developed on the basis of the environmental factors of the ICF-CY to initiate the narration. Certain topics were brought up to support the interviewees in general and particularly those who were not used to speaking freely about their experiences. In addition, questions that arose during the flow of speech were added accordingly to deepen the understanding of backgrounds and coherences.

In the second phase of field research, interview guidelines were developed in the form of a "pool of questions". This pool included questions that were identified to be of possible interest based on the data from the first phase. Moreover, before each interview, the previous interviews that had been conducted in the first phase with the same person were examined in regard to any existing links and emerging topics and to clarify unclear statements. Additionally, narrative methods were used where possible.

Furthermore, focus group discussions were considered as very fruitful. As mentioned earlier, questionnaires that had been used for the larger project led to adding this new method to the research process. During the first phase of the field research, illiterate parents discussed questions which the research team had to read out to them from the questionnaires. In this way, focus group discussions emerged without my intention. Realising that these discussions contained interesting aspects for the research at hand, an additional informed consent was produced, and discussions were taped with the parents' permissions. These questionnaires had initially been developed only for the comparative larger project and were not intended to be used for the book at hand. They had been used by me during the field research for collecting quantitative data in order to compare the three countries in another paper. However, the unforeseen discussions provided me with valuable data. Consequently, the focus group discussions were implemented as a fixed part of the qualitative research instruments in the second phase of the field research, not only for parents but also for children. 
As to the interviews with children, different materials were used. Next to cue cards, cards with different topics, cameras for the children to take pictures of their favourite locations, people, etc. in the school, games (throwing a dice with pictures/topics, a miniature of a classroom with children, teachers, desks, etc.) and hand puppets were used in case children found it difficult to feel free or interact with the research team. The materials were also adapted for their use for blind children. Experience showed that the hand puppet was one of the best items for getting access to the children. Additionally, the focus group discussions with children worked very well.

Regarding the observations, I and my Ethiopian assistant Yeshitla visited the classrooms during the lessons. Yeshitla and me developed guidelines for observation in advance, and both of us made our observations independently. The same procedure was followed in the appraisal of the school compounds where aspects like accessibility, traffic in front of the school, toilets, condition of the schoolyard, classrooms, etc. were examined. In this way, new impressions and information could be obtained that otherwise might not have been gathered with such quality. Having this information from an etic (me) as well as from an emic (Yeshitla) perspective added to the possibility to be critical towards possible cultural bias.

Having the option to visit the field on several occasions opened lots of new possibilities. One positive aspect was certainly that the participants' level of confidence increased and relationships could be established. This was particularly significant for the interviews with children.

Besides, regarding the theoretical level of grounded theory and by referring to the early publications of Glaser and Strauss, Charmaz highlights the "[s]imultaneous involvement in data collection and analysis" as one of the essential elements when using grounded theory in practice $(2006,5)$. Therefore, analysis of data was an ongoing process throughout the data collection. Data was constantly being compared, while next steps of interviewing were decided on. The construction of analytic codes and categories by working with the data took place throughout the field research. Charmaz - in reference to Glaser and Strauss - speaks of this process as one of the pillars when "doing" grounded theory, as it is important that these codes and categories are drawn from the data directly as opposed to deriving them from earlier formulated hypotheses by following a deductive way of inquiry (Charmaz 2006). These aspects are more related to the chapter of analysing the data; nevertheless they are also relevant at this point because they illustrate how interconnected the steps of data collection and data analysis were throughout the research process. This is important because "[...] data form the foundation of our theory and our analysis of these data generates the concepts we construct. Grounded theorists collect data to develop theoretical analyses from the beginning of a project" (Charmaz 2006, 2).

\section{The Sample}

The proposal for the larger project had clear indications regarding the sample to start with into the field. The target group of the investigation included children who had different structural and functional disabilities in the areas of hearing, sight, 
intellectual abilities and motor activities (OECD 2005; Terzi 2008; WHO 2001, 2007). The minimum size of the sample was $n=8$ (cases). This number resulted from the goal of including two children of each "group of disabilities" (hearing, visual, intellectual and physical disability), one male and one female child. In order to reach the number of eight cases by the end of the project, the initial sample was aspired to contain 16 cases. Specific information about the collected data can be found in the subchapter on "participants".

The age range of the sample was to reach from 8 to 12 . This age range was chosen based on the fact that school attendance is free and compulsory in Ethiopia for children aged 7-14 (Ethiopian Ministry of Education 2011a). Furthermore, the individual development of the child had to be considered. Hence, the phase of childhood ought to be at the centre of the research rather than adolescence. Additionally, the children of the sample should be assignable according to the cross-national OECD category A, "disabilities" that include children with somatic impairments (OECD 2005). Such a research outline sounds inappropriate indeed after having read the introductory parts of this study. Classifications, age ranges, different "types" of disabilities do not comply with the overall goal of stepping aside from such categorisations and seeing disability from an environmental and social perspective. Therefore, apart from the project proposal, realities had to be faced during the investigation and categorisations had to be overlooked for the independent research project at a certain point of the research process. The predefined sample served pragmatic purposes; however, in-depth classifications were criticised and avoided where possible after having entered the field. This was done by analysing the data focusing on environmental, societal and cultural factors rather than on biomedical aspects related to disability. Additionally, the age range indicated above could not be complied with, as children with disabilities in Addis Ababa often do not start school at 7 years of age. In many cases, they only have the possibility to enter school at a later age. This happens because schools refuse to take them or because parents do not know about the possibility or do not want to send their child to school. Additionally, the age is in general not regarded as important, and births are not always reported officially. Hence, birth certificates often simply did not exist, and the year of birth was not known. This led to indications of the age of the children differing up to 5 years when asking teachers, parents and children. Therefore, the aspect of age was given less relevance in the research.

\section{Theoretical Sampling}

Theoretical sampling is the process of data collection for generating theory whereby the analyst jointly collects, codes, and analyzes his data and decides what data to collect next and where to find them, in order to develop his theory as it emerges. This process of data collection is controlled by the emerging ${ }^{2}$ theory, whether substantive or formal. [...] The

\footnotetext{
${ }^{2}$ In their first publications, Glaser and Strauss spoke of emergence, as they stressed that categories emerged directly from the data. However, they state: "Of course, the researcher does not approach reality as a tabula rasa. He must have a perspective that will help him see relevant data and abstract
} 
initial decisions [for a theoretical collection of data] are not based on a preconceived theoretical framework. (Glaser and Strauss 1967/2008, 45)

The process of deciding what data to collect next took place simultaneously with the data collection and analyses of the interviews from the predefined sample. In other words, theoretical sampling was used by adding cases and experts if more information was expected to be gained regarding certain topics that had come up during earlier interviews. Glaser and Strauss formulate the basic question regarding decisions in theoretical sampling as follows: "[W] hat groups or subgroups does one turn to next in data collection? And for what theoretical purpose? In short, how does the sociologist select multiple comparison groups?" (Glaser and Strauss 1967/2008, 47). Therefore, the decisions concerning the gathering of further information depended on theoretical considerations. Throughout this process, the way towards a theory was paved, as decisions to include certain topics and not to include others defined the phenomenon that was going to be investigated in depth. However, the researcher has to stay alert also in this situation in order to be able to keep his/her theoretical sensitivity and not become doctrinaire (Glaser and Strauss 1967/2008, 46).

The sociologist should also be sufficiently theoretically sensitive so that he can conceptualize and formulate a theory as it emerges from the data. [...] Theoretical sensitivity of a sociologist has two other characteristics [next to a continual development]. First, it involves his personal and temperamental bent. Second, it involves the sociologist's ability to have theoretical insight into his area of research, combined with an ability to make something of his insights. (Glaser and Strauss 1967/2008)

Hence, it is essential to reflect on the personal affinities as a researcher as well as having the talent to identify meaningful aspects that come up during the research. Lamnek (2005) describes theoretical sampling as a constantly developing process where comparison groups that have been chosen based on certain theoretical considerations from the first phase of research are analysed. This analysis takes place by focusing on selected considerations that have been identified as crucial for the further development of the emerging theory. It is thus not the goal to capture all features of all data of the comparison groups. The main criteria for the theoretical decisions follow theoretical goals and are of theoretical relevance (Lamnek 2005, 106). This comparative analysis enriches the diversity and intensity of the whole analysis (Lamnek 2005, 107).

To give a short insight into the theoretical sampling of the book at hand, some examples are given here. During the research process, it was decided to include interviews with religious representatives, as it became clear that religion plays an important role regarding perceptions of disability. Furthermore, different NGOs and other organisations in Addis Ababa were consulted as they were mentioned in the interviews as points of reference. Additionally, at one point, it became apparent that teacher education was an important issue amongst some of the participants. Hence, a teacher training college was visited for interviews as well as the university, where

significant categories from his scrutiny of the data" (Glaser and Strauss 1967/2008, 3). In the book at hand, when talking about emerging categories, subcategories, etc., it has to be understood always from a constructivist point of view. Hence, emerging categories were always also constructed by the researcher herself. 
teachers studying special needs education were interviewed. Moreover, the Ministry of Education was consulted several times in order to conduct interviews with the Minister, special needs experts and consultants in order to get more information about political developments regarding special needs education. More information about the participants of the research project will be given in detail below.

\section{Site Selection}

The goal was to include schools from as many different areas of the city as possible in order to obtain a broader picture of the situation of the schools also regarding geographical circumstances within Addis Ababa. The 16 cases that were aimed at provided us with the possibility of choosing eight schools, as in each school one girl and one boy was to be interviewed $(8 \times 2=16)$. Additionally, this provided the possibility to include more schools. Theoretically, the sample would be drawn from two schools of each "disability group" (two schools teaching children with hearing, visual, physical and intellectual disabilities respectively). In each school, one boy and one girl would be included in the sample.

The selection of locations for conducting interviews included several challenges. Naturally, it was a problem to find children with disabilities in the schools visited that matched the ideas regarding the kind of disability, age and gender. However, in some cases, people in the streets of the districts chosen could tell the research team where to find schools that accepted children with disabilities. Nevertheless, the main problem was to find children who matched the defined age group of 8-12.

Seven schools were eventually included in the field research. Two of these accepted children with physical or multiple disabilities (e.g. a combination of speech problems and the need to use a crutch), two had special units for children with intellectual disabilities, one was a special school for the deaf, one had a special unit for children with hearing disabilities, and one was an integrative school specialised in children with visual problems. All of the schools were free of charge (no tuition fees had to be paid). Five schools were governmental schools. This indicates that they should be accessible for all children. Usually, those schools are frequented by children from poor families. Children from wealthier families attend public or private schools which collect tuition fees and in most cases offer a better quality of education. The last two schools were supported by different churches. It was by intention that schools accessible to the majority of the (poor) population were chosen. The following graph illustrates the characteristics of the schools and the cases interviewed. The numbers reflect the situation of the school year 2010/2011 (Table 12.1).

It was interesting to observe that in all schools there were about $10 \%$ more female students than male students. The same was true regarding the numbers of teachers. Nevertheless, the higher the grades, the fewer female students could be found. 
Table 12.1 Description of sample schools

\begin{tabular}{|c|c|c|c|c|c|c|}
\hline School & $\begin{array}{l}\text { School type and } \\
\text { location }\end{array}$ & $\begin{array}{l}\text { No. of } \\
\text { students }\end{array}$ & $\begin{array}{l}\text { No. of } \\
\text { teachers }\end{array}$ & $\begin{array}{l}\text { Disability } \\
\text { related } \\
\text { information }\end{array}$ & $\mathrm{N}^{\circ}$ of $\mathrm{SwD}^{\mathrm{a}}$ & $\begin{array}{l}\text { Interviewed } \\
\text { SwD }\end{array}$ \\
\hline \multirow[t]{3}{*}{ A } & Governmental & \multirow[t]{3}{*}{2365} & \multirow[t]{3}{*}{74} & \multirow{3}{*}{$\begin{array}{l}\text { Accepted } \\
\text { children with } \\
\text { physical and } \\
\text { visual } \\
\text { disabilities, } \\
\text { integrative } \\
\text { setting }\end{array}$} & \multirow[t]{3}{*}{13} & $\begin{array}{l}3 \text { cases } \\
(2 \mathrm{f} / 1 \mathrm{~m})\end{array}$ \\
\hline & Grades $1-8$ & & & & & \multirow{2}{*}{$\begin{array}{l}4 \mathrm{SwD} \text { in a } \\
\mathrm{FGD}^{\mathrm{b}}\end{array}$} \\
\hline & $\begin{array}{l}\text { Poor area, not } \\
\text { central, in the } \\
\text { hills }\end{array}$ & & & & & \\
\hline \multirow[t]{3}{*}{ B } & Governmental & \multirow[t]{3}{*}{1810} & \multirow[t]{3}{*}{85} & \multirow{3}{*}{$\begin{array}{l}\text { Accepted } \\
\text { children with } \\
\text { physical } \\
\text { disabilities, } \\
\text { integrative } \\
\text { setting }\end{array}$} & \multirow[t]{3}{*}{8} & 2 cases $(2 f)$ \\
\hline & Grades $1-8$ & & & & & $4 \mathrm{SwD}$ in a \\
\hline & $\begin{array}{l}\text { Poor area in the } \\
\text { outskirts }\end{array}$ & & & & & FGD \\
\hline \multirow[t]{3}{*}{$\mathrm{C}$} & Governmental & \multirow[t]{3}{*}{1752} & \multirow[t]{3}{*}{81} & \multirow{3}{*}{$\begin{array}{l}\text { Accepted } \\
\text { children with } \\
\text { physical and } \\
\text { intellectual } \\
\text { disabilities, } \\
\text { special units } \\
\text { for children } \\
\text { with } \\
\text { intellectual } \\
\text { disabilities: } \\
\text { special setting }\end{array}$} & \multirow{3}{*}{\begin{tabular}{|l|}
32 \\
integrated \\
38 special \\
unit \\
\\
\\
\end{tabular}} & $\begin{array}{l}3 \text { cases } \\
(1 \mathrm{f} / 2 \mathrm{~m})\end{array}$ \\
\hline & Grades $1-8$ & & & & & 4 students in \\
\hline & $\begin{array}{l}\text { Relatively central } \\
\text { area, on a hill }\end{array}$ & & & & & $\begin{array}{l}\text { a FGD (1 } \\
\text { SwD) }\end{array}$ \\
\hline \multirow[t]{3}{*}{$\mathrm{D}$} & Governmental & \multirow[t]{3}{*}{1899} & \multirow[t]{3}{*}{85} & \multirow{3}{*}{$\begin{array}{l}\text { Accepted } \\
\text { children with } \\
\text { physical and } \\
\text { intellectual } \\
\text { disabilities, } \\
\text { special units } \\
\text { for children } \\
\text { with } \\
\text { intellectual } \\
\text { disabilities: } \\
\text { special setting }\end{array}$} & \multirow[t]{3}{*}{24} & $\begin{array}{l}2 \text { cases } \\
(1 \mathrm{f} / 1 \mathrm{~m})\end{array}$ \\
\hline & Grades 1-8 & & & & & $4 \mathrm{SwD}$ in a \\
\hline & $\begin{array}{l}\text { Relatively poor } \\
\text { area, not central, } \\
\text { on a hill }\end{array}$ & & & & & FGD \\
\hline \multirow[t]{3}{*}{$\mathrm{E}$} & $\begin{array}{l}\text { Supported by the } \\
\text { church }\end{array}$ & \multirow[t]{3}{*}{541} & \multirow[t]{3}{*}{23} & \multirow{3}{*}{$\begin{array}{l}\text { Accepted } \\
\text { children with } \\
\text { visual and } \\
\text { physical } \\
\text { disabilities, } \\
\text { integrative } \\
\text { setting }\end{array}$} & \multirow[t]{3}{*}{$?$} & \multirow[t]{3}{*}{$\begin{array}{l}4 \text { cases } \\
(1 \mathrm{f} / 2 \mathrm{~m})\end{array}$} \\
\hline & Grades $1-8$ & & & & & \\
\hline & Central area & & & & & \\
\hline
\end{tabular}


Table 12.1 (continued)

\begin{tabular}{|c|c|c|c|c|c|c|}
\hline School & $\begin{array}{l}\text { School type and } \\
\text { location }\end{array}$ & $\begin{array}{l}\text { No. of } \\
\text { students }\end{array}$ & $\begin{array}{l}\text { No. of } \\
\text { teachers }\end{array}$ & $\begin{array}{l}\text { Disability } \\
\text { related } \\
\text { information }\end{array}$ & $\mathrm{N}^{\circ}$ of $\mathrm{SwD}^{\mathrm{a}}$ & $\begin{array}{l}\text { Interviewed } \\
\text { SwD }\end{array}$ \\
\hline \multirow[t]{3}{*}{$\mathrm{F}$} & $\begin{array}{l}\text { Supported by the } \\
\text { church }\end{array}$ & \multirow[t]{3}{*}{98} & \multirow[t]{3}{*}{14} & \multirow{3}{*}{$\begin{array}{l}\text { Special } \\
\text { school for } \\
\text { children with } \\
\text { visual } \\
\text { disabilities: } \\
\text { special setting }\end{array}$} & \multirow[t]{3}{*}{98} & $\begin{array}{l}4 \text { cases } \\
(2 \mathrm{f} / 2 \mathrm{~m})\end{array}$ \\
\hline & Grades 1-6 & & & & & \multirow{2}{*}{$\begin{array}{l}4 \mathrm{SwD} \text { in a } \\
\text { FGD }\end{array}$} \\
\hline & $\begin{array}{l}\text { Not very central } \\
\text { area }\end{array}$ & & & & & \\
\hline \multirow[t]{3}{*}{ G } & Governmental & \multirow[t]{3}{*}{1614} & \multirow[t]{3}{*}{91} & \multirow{3}{*}{$\begin{array}{l}\text { Accepted } \\
\text { children with } \\
\text { hearing } \\
\text { disabilities, } \\
\text { special units } \\
\text { for children } \\
\text { with hearing } \\
\text { disabilities; } \\
\text { special setting }\end{array}$} & \multirow[t]{3}{*}{92} & \multirow{3}{*}{$\begin{array}{l}2 \text { cases } \\
(1 \mathrm{f} / 1 \mathrm{~m})\end{array}$} \\
\hline & Grades $1-8$ & & & & & \\
\hline & Central area & & & & & \\
\hline Total & & & & & & 20 cases \\
\hline
\end{tabular}

${ }^{a}$ Students with disabilities

${ }^{\mathrm{b} F o c u s}$ group discussion

\section{Participants}

Having followed theoretical sampling throughout the different phases of the field research, the sample that resulted for the research project in the first phase of the field research consisted of ${ }^{3}$ :

- Twenty cases (child-parent-teacher)

- Ten experts from within the schools (principals, special needs experts)

- Two experts from outside schools (general special needs education expert, teaching staff from the Department of Special Needs Education of Addis Ababa University)

- Two focus group discussions (parents), resulting in 74 interviews

Additionally the following data was collected in order to obtain more information also on a level other than face-to-face discussions:

- Twenty class observations

- Seven appraisals of school compounds

- Writing of a research diary

\footnotetext{
${ }^{3}$ In the preparatory phase, first interviews had already been conducted in the Ministry of Education and the associations for the blind, for the deaf and for the "intellectually disabled" about the general situation of persons with disabilities. This took place in the framework of getting information for a new project (RESPOND-HER; for more information see http://respond-her.univie.ac.at/). However, it also provided the researcher with some information on the general situation of persons with disabilities in Ethiopia.
} 
Before the second phase of the field research started, 8 of the 20 cases were chosen for deeper analysis after having analysed the first set of interviews. This decision was made with the aim of achieving the greatest diversity of participants - and not beyond - within the sample. Too many data are not considered to make sense, as could be deduced from the abundance of data from the first phase. However, during the first analysis of the cases and the expert interviews of the first phase, open questions as well as first categories and emerging topics were identified.

In the second phase of the field research, the mentioned eight cases were reinterviewed (in cases where children had left the school, or opted out etc. another case out of the 20 was chosen to replace the student). This research phase resulted in:

- Eight cases (child-parent-teacher)

- Six experts from within the schools (principals, special needs experts)

- Seven focus group discussions with parents

- Five focus group discussions with children

- Five experts from outside schools (Minister of Education, special needs expert from the Ministry of Education, Finnish advisor to the Minister of Education, expert from the Ethiopian Centre for Disability and Development, administrative head of the Ethiopian Orthodox Tewahedo church), resulting in 47 interviews

The third phase of the field research followed similar guidelines. Analyses of interviews had been conducted as far as possible (the dates for the field research were predefined and were hence not very flexible). According to the results, the last opportunity to conduct interviews resulted in interviews with:

- ENDAN (Ethiopian National Disability Action Network)

- LIGHT FOR THE WORLD Austria (Expert for Ethiopia)

- Teacher Training College Ethiopia (head of the Department of Special Needs Education)

- Dean of the College of Education at Addis Ababa University

- RSDA (Rehabilitation Service for the Deaf Association)

- Expert for teacher education

- Focus group discussion with students of the Department of Special Needs Education, Addis Ababa University

- [Observation of an "inclusive" class (integration of children with hearing disabilities)], resulting in seven interviews

The amount of data collected was still considered extensive. Hence, focused coding was used to be able to manage bigger amounts of data, as will be explained later.

The following table gives an overview of data of the 20 children and parents who were interviewed. They are the original data as collected in autumn 2010. 


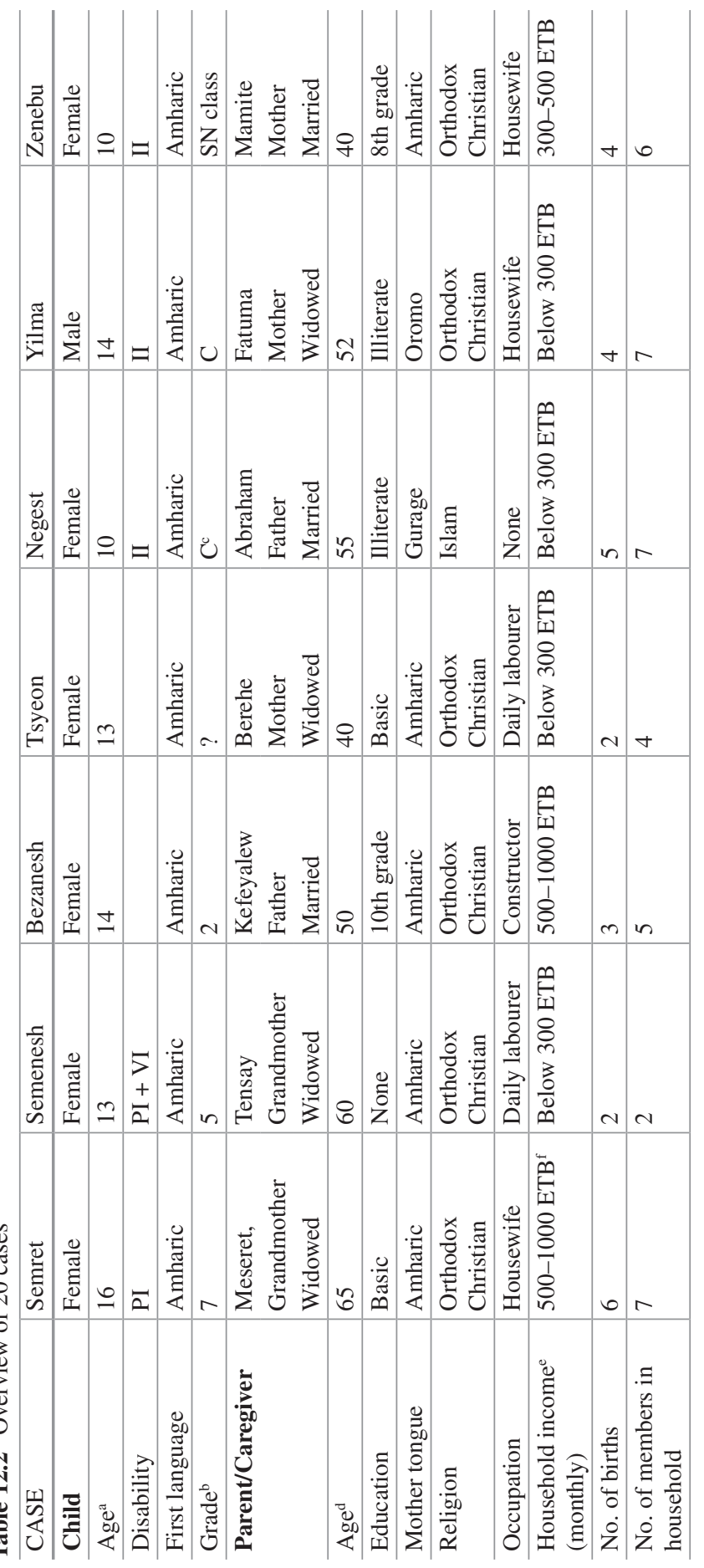




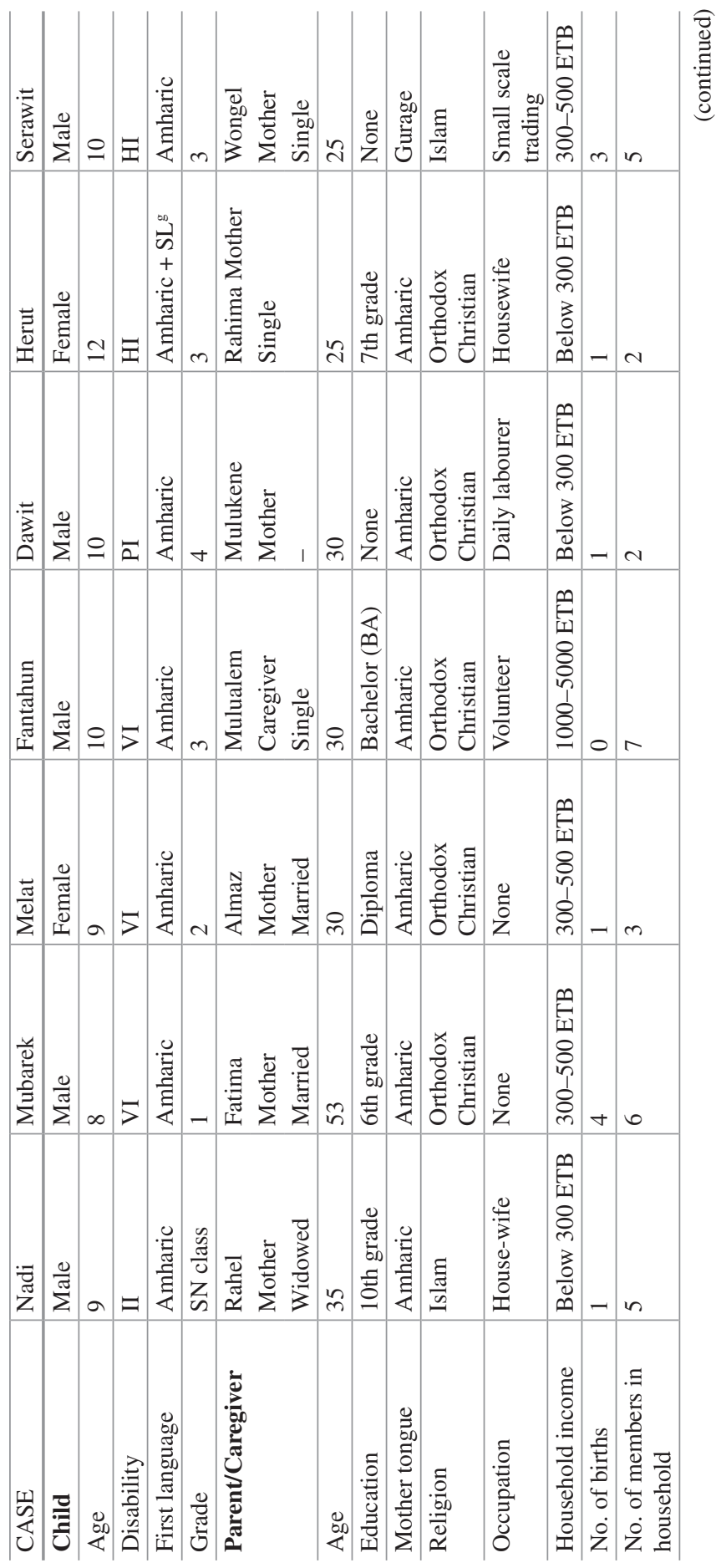




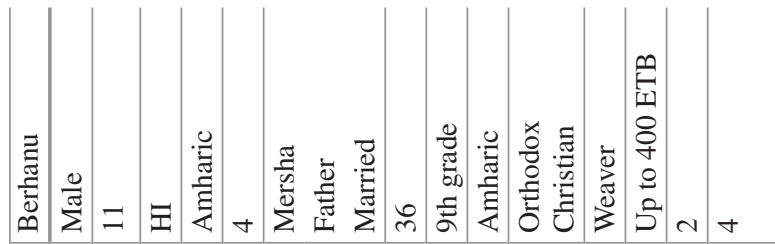

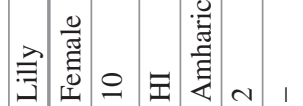

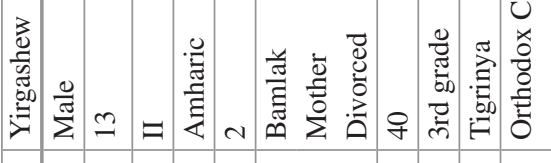

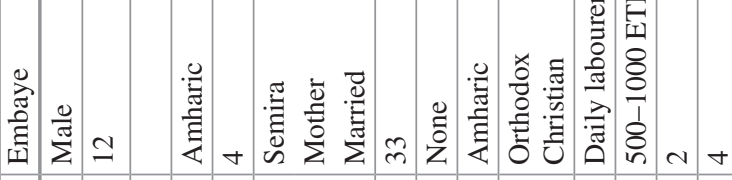

离

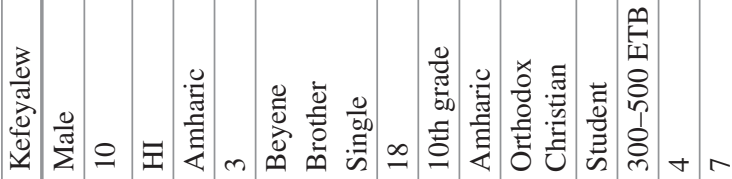

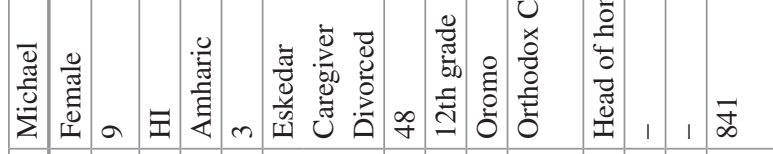

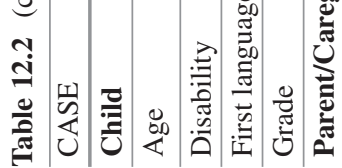

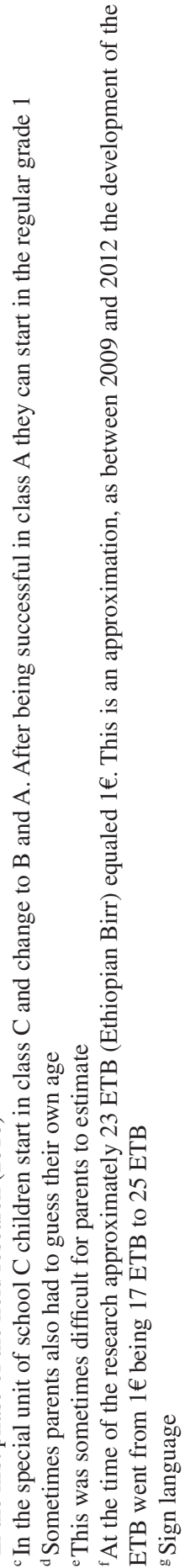




\section{Socio-economic Background}

More than $80 \%$ of the families (parents ${ }^{4}$ and children) involved in the research originated from a poor or very poor background. In other words, they had a daily income below $2 €$. Many of the parents were daily labourers with no fixed income. As indicated above, this was the case because of the intention to only include governmental schools, which were free from tuition fees and therefore affordable for poor families. As far as ethnical backgrounds are concerned, most of the participants were Amhara of descent. However, a small percentage also originated from Oromo, Guraghe, Tigrinya or other ethnic groups. Despite the different descents, all of the children were raised speaking the Amharic language. The number of family members was, unexpectedly, usually not high and between (in most cases) two and four and (in few cases) up to seven persons. Sometimes the reason for avoiding having more children was the disability of the child itself or the fact that the mother and child/children lived in the city while the father stayed somewhere else to work. Additionally, almost half of the children did not live with both parents or with neither parent. Some parents were widowed or children had been given to relatives (aunts, grandmothers, etc.) and child care institutions.

\section{References}

Charmaz, K. (2006). Constructing grounded theory: A practical guide through qualitative analysis. London/Thousand Oaks/New Delhi: Sage.

Clandinin, D. J. (Ed.). (2007). Handbook of narrative inquiry. Mapping a methodology. Thousand Oaks: Sage.

Denzin, N. K., \& Lincoln, Y. S. (Eds.). (2005). The sage handbook of qualitative research. Thousand Oaks/London/New Delhi: Sage.

Ethiopian Ministry of Education. (2011). Education sector development program IV (ESDP IV). 2010/2011-2014/2015. Addis Ababa: Ethiopian Ministry of Education.

Friebertshäuser, B., \& Prengel, A. (1997). Handbuch qualitative Forschungsmethoden in der Erziehungswissenschaft. Weinheim: Juventa.

Glaser, B. G., \& Strauss, A. L. (1967/2008). The discovery of grounded theory: Strategies for qualitative research. New Brunswick: Aldine Transaction.

Glinka, H.-J. (2009). Das narrative interview. Weinheim/München: Juventa Verlag.

Lamnek, S. (2005). Qualitative Sozialforschung. Lehrbuch. Weinheim: Beltz.

\footnotetext{
${ }^{4}$ Including caregivers.
} 
OECD. (2005). Center for educational research and innovation: Students with disabilities, learning difficulties and disadvantages. Statistics and indicators. Paris: OECD.

Terzi, L. (2008). Beyond the dilemma of difference. The capability approach in disability and special educational needs. In L. Florian \& M. J. McLaughlin (Eds.), Disability classification in education. Issues and perspectives (pp. 244-262). Thousand Oaks/London/New Delhi/ Singapore: Corwin Press.

WHO. (2001). International classification of functioning, disability and health. Geneva: World Health Organization.

WHO. (2007). International classification of functioning, disability and health. Children \& youth version. Geneva: World Health Organization.

Open Access This chapter is licensed under the terms of the Creative Commons Attribution 4.0 International License (http://creativecommons.org/licenses/by/4.0/), which permits use, sharing, adaptation, distribution and reproduction in any medium or format, as long as you give appropriate credit to the original author(s) and the source, provide a link to the Creative Commons license and indicate if changes were made.

The images or other third party material in this chapter are included in the chapter's Creative Commons license, unless indicated otherwise in a credit line to the material. If material is not included in the chapter's Creative Commons license and your intended use is not permitted by statutory regulation or exceeds the permitted use, you will need to obtain permission directly from the copyright holder.

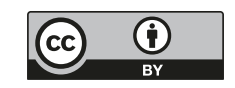

